UNITED STATES SCHOOL GARDEN ARMY DEPARTMENT OF THE INTERIOR GARDEN MANUAL No. 1

$$
U \cdot S \cdot S \cdot G
$$

BUREAU OF EDUCATION WASHINGTON

\title{
LESSONS IN GARDENING FOR THE CENTRAL STATES REGION
}

\section{FOLLOW THE PIED PIPER}

Join the United States School Garden Army.

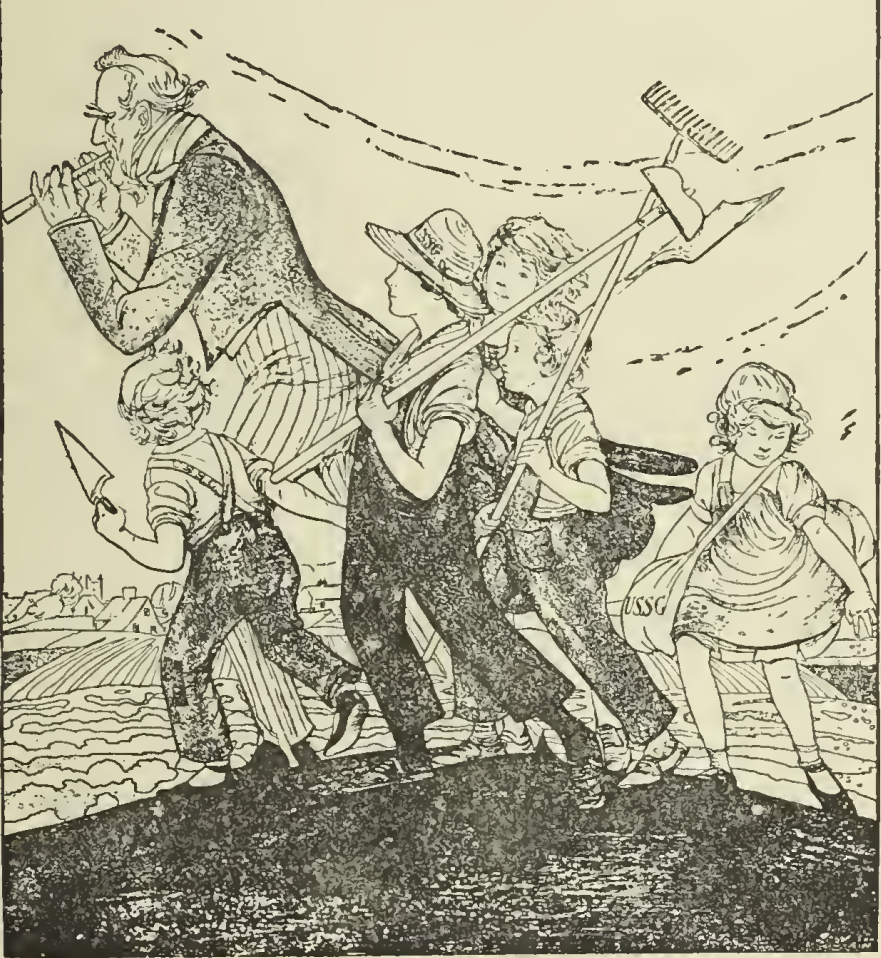




\section{LESSONS IN GARDENING FOR THE CENTRAL STATES REGION.}

GARDEN MANUAL NO. 1.

The following 25 lessons in gardening are intended for the use of teachers and supervisors of gardening. They constitute Garden Manual No. 1, and are based upon the leaflets that hare already been issued for the Central States region by the United States School Garden Army. The subject matter contained in each lesson can easily be taught during a 15-minute period by any teacher that has an interest in gardening.

These lessons can be made a part of the regular work in nature study, elementary science, elementary agriculture, or garden work. They are suitable for any grade above the third.

\section{Group 1-GETTING READY TO PLANT.}

Lesson 1. First Catch Your Rabbit.

2. How to Prepare Your Garden.

3. How to Plan Your Garden.

4. Companion Crops.

5. Succession Crops.

6. A One-Crop Plan for a Small Garden.

7. A Double-Crop Plan for a Garden 60 by 50 Feet.

8. Buying Garden Seed.

9. Quantity of Seed to Buy.

10. Varieties of Seed to Buy.

11. When to Plant in the Central States.

12. How to Plant.

13. Commercial Fertilizers for the Garden.

14. Testing Garden Seed.
Group II-PLANTING AND CARING FOR THE CROPS.

Lesson 15. Growing and Transplanting Plants.

16. Thinning the Crops.

17. Replanting the Crops.

18. Lettuce.

19. Radishes.

20. Peas.

21. Onions.

22. Irish Potatoes.

23. Beets.

24. Cabbage.

25. Carrots.

Garden Manual No. 2 will contain lessons on the later garden crops, as well as methods of preventing and destroying plant diseases and insects that injure these crops. 


\section{LESSONS IN GARDENING FOR THE CENTRAL STATES REGION.}

\section{Group I.-GETTING READY TO PLANT.}

\section{Lesson One: FIRST, CATCH YOUR RABBIT.}

You remember the story of the boy who was telling about the rabbit he was going to eat, and his father said, "Son, first catch your rabbit." Well, that's the way you must do with these school gardens. Before you call eat the crops you expect to grow, you must get the garden.

For you boys and girls living in the country this will probably be an easy matter. Your fathers will be glad to give you a piece of land for your own use, as large as you are able to handle, where you can grow as many kinds of crops as you wish.

For you boys and girls living in the towns or cities it may be a little harder to get the land for your garden. But many of you will have a back yard of your own where many vegetables can be grown; or your next-door neighbor will be glad to let you use his back yard. At any rate, don't be discouraged if you can't find a place for your garlen the first thing. By looking around and sticking to it you will find that there are a great many back yards and racant lots near your own home which the owners will be proud to let you use after you have told them of the wonderful work the School Garden Army is doing.

If your garlen is to be in a back yard, pick out one that is not shaded too much by trees or buildings. Growing things need sunlight and plenty of it. And try to pick out land that isn't all clay or gravel. You can't expect to grow much on soil like that. Ask one of your friends who has a garden of his own to help you pick out the right place for your garden.

\section{Lesson Two: HOW TO PREPARE YOUR GARDEN.}

The soil for your garden should be spaded or plowed if possible in the fall. If this can not be done, then you should do it as early in the spring as possible. If your garden is too small to be plowed with a team, you should spade it deeply with a spading fork. Deep plowing and spading, followed by thorough harrowing and raking, puts the soil in the best condition to make your plants grow. When the soil is spaded, each spadeful as it is turned over should be broken up by striking with the back of the spade. When your garden soil crumbles in your hands, it is just right.

Vegetables are heavy feeders and, therefore, they need a rich soil. Many experienced gardeners use what is known as compost on their gardens. A compost heap is made of a mixture of meadow sod, leaves, straw, grass, lawn clippings, unused portions of food and vegetables, sweepings from unoiled streets, lime or wood ashes, stable manure, and soil. The plan usually followed is to first spread out a layer of manure about 4 inches deep, then one of leaves or straw or vegetable waste. Upon these sprinkle a small quantity of lime or wood ashes; then follow with a 
layer of earth an inch or two thick. Repeat this until all your material has been arranged in layers and placed in piles. Alternate layers of leaves or straw prevent the plant food contained in the stable fertilizer and street sweepings from being washed out and lost.

Turn over your compost heap with a sparling fork about twice a season. This mixes the materials more thoroughly and makes them decay more. In a dry climate you should pour water on the heap occasionally.

As soon as part of your compost heap has rotted down enough to mix readily with the soil it should be spaded in wherever needed. The coarser portions which are slow to decay may well be buried in the bottom of border beds for perennial flowers or vegetables.

The thorough working into the soil of any stable or commercial fertilizer is important. Gardèn soils composed largely of clay are very likely to be sour, but you can fix this by putting 1 pound of air-slacked, burned, or hydrated lime; 2 pounds of ground limestone; or 3 pounds of unleached wood ashes on every 25 square feet of garden space. Coal ashes will help to loosen up a clay soil.

The proper preparation of the soil and thorough working of all fertilizers into the soil are of utmost importance. The success of your garden will depend very largely upon the thoroughness with which your seed bed has been prepared.

\section{Lesson Three: HOW TO PLAN YOUR GARDEN.}

Many of us think of gardening as work to be done only during a few brief weeks in the spring. This is wrong. Your garden will do its best for you if plans for it are made in the autumn and much of its preparation done then.

Here are some things you should think of in planning a garden:

1. Size.-The average boy or girl can casily spade and care for a garden 10 by 30 feet. A garden of this size will go far to supply vegetables for a family of four. Your garden should be sufficiently large to grow enough vegetables to make it worth while, but not so large as to make its care too much of a task.

2. Iridth between rows. - Rows must be farther apart if a horse or handwheel cultivator Is used than if you use hand tools, such as a hoe or rake.

3. Paths. - Since your plants must receive personal attention you should plan your garden with paths so that you can reach all parts of it without tramping down the plants.

4. Rotation.-This means using the same ground for the growth of one kind of crop, followed by another of a different kind, as a crop of corn followed by a crop of beans. Each plant has habits peculiar to itself. One plant may draw heavily on soil potash, another on soil nitrogen. Besides, certain plants grown time after time in the same soil tend to poison it. Your planting schemes should avoid growing the same kind of plants over and over on the same ground.

5. Keeping your garden at work.-A planting calendar will tell you how, by second and third sowings, you can have fresh vegetables at all times during the gardening season.

6. Use all your land.- Vegetables which ripen quickly may be grown among those which ripen slowly. Thus lettuce, radishes, spinach, and like vegetables may be planted in the soil between tomato plants, potatoes, corn, etc.

7. Plants to grow.-The kinds of plants to be grown will determine very largely the nature of your plan. Radishes and lettuce may be planted closer together than cabbages or corn.

8. Adding a touch of beauty.-Finally, if you wish to make your garden not only productive but attractive, flowers may be grown about the borders. 


\section{Lesson Four: COMPANION CROPS.}

Some common examples of companion cropping are carried out by the following plans:

1. Slow-growing plants like melons, cabbages, and cauliflower occupy only a small space of ground for several weeks after planting. For this reason a few rows of early radishes, lettuce, or turnips may be grown between hills or rows of melons, cabbages, or cauliflower.

2. The plan suggested in former leaflets of marking rows of parsnips, carrots, or onions with radishes or lettuce is an example of companion cropping.

3. Many gardeners set lettuce plants between rows of early potatoes, tomatoes, or corn.

4. Plant pole beans in the hills of sweet corn or field corn or near a single sunflower plant. The cornstalks or sunflower plants will furnish support for the bean vine.

5. Pumpkins may be planted in the rows of corn, especially in large gardens.

6. When melon or cucumber hills are made 8 feet apart each way, plant two or three rows of early bunch beans between each row of melons or cucumbers. Pick the beans as soon as they are realy for table use. Pull the bean stalks after removing the beans from the stalks.

7. As the early potatoes begin to reach maturity and the vines show signs of turning brown, plant an early variety of sweet corn or sow turnip seed between the potato rows.

\section{Lesson Five: SUCCESSION CROPS.}

Some examples of succession cropping are suggested in lesson No. 7-the double-crop plan. Other suggestive methods are as follows:

1. Early lettuce, followed by celery.

2. Early radishes, followed by cabbage.

3. Early peas, followerl by late beets.

No gardener will care to plant all of these crops suggested in this lesson and lesson No. 7 , but will desire to use those best adapted to his local conditions.

\section{CROPS PLANTED AT TEN-DAY INTERVALS.}

The following crops may be planted at intervals of 10 days or 2 weeks:
Radishes.
Peas.
Spinach. Early Corn.
Early Turnips. Early Beets.
Dwarf Beans.
Lettuce.

This plan will insure a continuous supply of produce for the table throughout the growing season. 


\section{Lesson Six: A ONE-CROP PLAN FOR A SMALL GARDEN.}

The following form for a one-crop plan may prove suggestive in planning your garden, where the space for growing vegetables is very limited:

so feet long by 20 feet wide.

\begin{tabular}{|l|}
$\frac{12 \text { Dwarf Beans, early variety }}{12 \text { Dwarf Beans, early variety }}$ \\
$\frac{12 \text { Dwarf Beans, early variety (two weeks later) }}{12 \text { Dwarf Beans, late variety }}$ \\
$\frac{6 \text { Onion sets }}{6 \text { Onion sets }}$ \\
$\frac{6 \text { Radishes }}{6 \text { Radishes }}$ \\
$\frac{12 \text { Early Beets (marked with Radishes) }}{12 \text { Later Beets (marked with Radishes) }}$ \\
$\frac{24 \text { Lettuce (plants if possible) }}{24 \text { Lettuce (two weeks after first plant) }}$ \\
$\frac{12 \text { Spinach }}{24 \text { Peas, early }}$ \\
$\frac{24 \text { Peas, early }}{24 \text { Peas (two weeks after above planting) }}$ \\
$\frac{24 \text { Peas, late variety }}{24 \text { Turnips, early }}$ \\
$\frac{24 \text { Early Tomatoes }}{24 \text { Early Tomatoes }}$ \\
$\frac{24 \text { Late Tomatoes }}{12 \text { Peppers }}$ \\
\hline 1
\end{tabular}

Note. - The numbers on the leit indicate the distance in inches the rows are apart. 


\section{Lesson Seven: A DOUBLE-CROP PLAN FOR GARDEN.}

The following form may prove suggestive in planning a double-crop system for a garden:

First crop small letters-Second crop capital letters.

50 feet long by 60 fcet wide.

\begin{tabular}{|c|c|c|}
\hline & Onion sets & SWEET CORN \\
\hline \multicolumn{3}{|c|}{18 Onion sets } \\
\hline 18 & Lettuce & SWEET CORN \\
\hline \multicolumn{3}{|c|}{18 Early Beets } \\
\hline 18 & Early Beets & SWEET CORN \\
\hline 18 & Early Peas & \\
\hline 18 & Early Peas & SWEET CORN \\
\hline \multicolumn{3}{|c|}{24 Bush Beans } \\
\hline 24 & Bush Beans & LATE CABBAGE \\
\hline \multicolumn{3}{|c|}{24 Bush Beans } \\
\hline 18 & Carrots & LATE CABBAGE \\
\hline \multicolumn{3}{|c|}{18 Carrots } \\
\hline 18 & Radishes & LATE CABBAGE \\
\hline 30 & Early Potatoes & WINTER RADISHES \\
\hline 30 & Early Potatoes & TURNIPS \\
\hline 30 & Early Potatoes & TURNIPS \\
\hline 30 & Early Potatoes & TURNIPS \\
\hline 30 & Early Potatoes & TURNIPS \\
\hline 18 & Spinach & TOMATOES \\
\hline \multicolumn{3}{|c|}{18 Parsnips } \\
\hline 24 & Spinach & TOMATOES \\
\hline \multicolumn{3}{|c|}{24 Endive or Parsley } \\
\hline 24 & Peppers & LIMA BEANS (POLE) \\
\hline \multicolumn{3}{|c|}{12 Onions from seed } \\
\hline & Onions from seed & LIMA BEANS (POLE) \\
\hline \multicolumn{3}{|c|}{12 Onions from seed } \\
\hline & Asparagus bed & WINTER ONIONS RHUBARB \\
\hline
\end{tabular}

Note.-The numbers on the left indicate the distance in inches the rows are apart.

Gardens of the larger size permit of greater space between the rows and hence easier cultivation.

\section{Lesson Eight: BU YING GARDEN SEED.}

The best seeds have had their ancestors carefully selected by the men who grew them. The fields in which they were being produced have been gone over frequently and all unpromising plants removed. This has left for seed production only those true to the type desired. 
Such selection costs money. So the selected seeds are likely to be a little higher in price than those unselected. But they are well worth the difference. The reputable seedsmen make it a rule to handle only selected seeds.

The first result of selection is the production of standard varieties. It is important, therefore, for a pupil to buy seed recognized as a standard variety rather than simply a packet of seed. He is likely to get a better crop and at the same time learn to recognize good seed.

So in planning for the seed order, the first thing is to plan to buy good seed and the second is to plan to buy named varieties.

Seeds may be bought in bulk much cheaper than in packets. The making of small envelopes or seed packets is an excellent school exercise. So is the dividing of seeds in bulk into small sets. 'The working out of the cost of the smaller portions when a pound is so divided, furnishes a good problem in arithmetic.

The following suggestions are therefore made as to the buying of seeds:

1. Where practicable buy in bulk of reliable seed houses, and subdivide the seeds with the help of the pupils.

2. Buy named varieties, selecting either those recommended on the lists sent out from this office or those which have been found successful by local gardeners. An excellent way to get the pupils interested is to ask them to find out the names of successful varieties grown locally by home or professional gardeners.

3. When the seeds are bought in prepared packets, get named varieties if possible.

\section{Lesson Nine: QUANTIT Y OF SEED TO BUY.}

The United States Department of Agriculture in their Farmers' Bulletin No. 934, suggests the following amounts of the various kinds of seed to be a sufficient quantity for a family of four persons. 'Taking these amounts as a basis, a soldier in the U. S. S. G. A. can make an estimate as to the proper amount of seed to purchase before actual planting time arrives. In fact, the figuring of the amounts is a splendid school exercise for the children. It will make school arithmetic a live subject in the minds of the pupils.

Bean:

Bush Lima..................... 1 pint.

Pole Lima.................... 1 pint.

Snap......................... 1 to 2 quarts.

Beet............................ 4 ounces.

Cabbage:

Early....................... 1 packet.

Late...........................

Carrot........................... 1 ounce.

Cauliflower ........................ 1 packet.

Celery .......................... l lpacket.

Corn, Sweet.................... 1 to 2 pints.

Cucumber......................... 1 ounce.

Eggplant.......................... 1 packet.

Kale......................... 2 ounces.

Lettuce.......................... $\frac{1}{2}$ ounce.

Melon:

Muskmelon....................... 1 ounce.

Watermelon...................... 1 ounce.

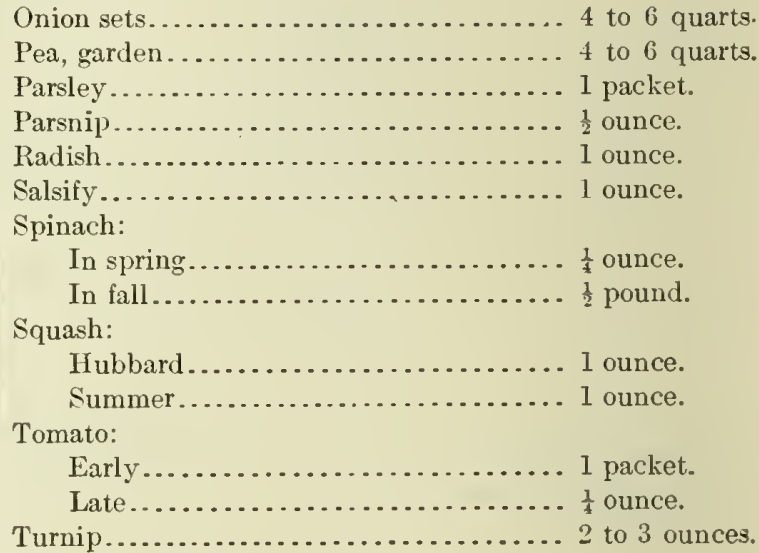

Turnip............................. 2 to 3 ounces.

'The above amounts will furnish a sufficient quantity of seed for succession cropping and will provide a surplus for canning, drying, and storing. 


\title{
Lesson Ten: VARIETIES OF SEED TO BUY.
}

\author{
VEGETABLES.
}

VARIETY.

Beans, green bush..........Green Pod-Red Valentine.

Beans, green pole...........Kentucky Wonder.

Beans, bush lima........... Landreth-Burpee's Bush.

Beans, pole lima.......... Seidert-Ideal.

Beets, red................. Crosby's Egyptian-Detroit Red.

Cabbage, early............Jersey Wakefield - Copenhagen.

Cabbage, late............Flat Dutch-Danish Ball Head.

Carrots.................... French Forcing-IIalf Long Scarlet.

Celery ................. Easy Blanching-Columbia.

Corn, sweet................ Country Gentleman-Golden Bantam.

Cucumber...............Emerald-White Spine.

Lettuce, leaf............ Grand Rapids-Blackseeded.

Lettuce, head............ Big Boston-May King.

Onion sets................ White Silverskin.

Onion dry.............. Yellow Globe-Silver King.

Parsley....................Plain Leaved-Moss Curled.

Parsnip............... Hollow Crown-Sugar.

Peas.................... Telephone-American Wonder.

Potatoes................. Early Ohio-lrish Cobbler-Early Rose.

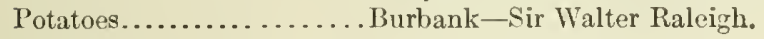

Radish, early............ Scarlet Globe-Short Top.

Radish, summer...........White Icicle.

Radish, winter...........Japanese.

Tomato................... Red Rock-Jewel.

Turnip, white........... White Globe-Purple Top Globe.

The above suggested varieties have proven dependable throughout the States comprising the Central Division. This list should be kept in a convenient place for use in connection with purchasing seeds for your garden.

\section{Lesson Eleven: WHEN TO PLANT IN THE CENTRAL STATES.}

Boys and girls in their public-school work in geography are called upon to study the "zones." They learn to think of them as heat belts. These heat belts, for reasons that are taught in geography, cause gardeners much study of the proper time to plant.

We have found that in Kansas, Missouri, southern Iowa, Illinois, Indiana, and the southern half of Ohio the planting dates for the same crops are similar. This section we will call zone E. Nebraska, northern Iowa, southern Wisconsin, southern Michigan, northern Ohio, because of similar climatic conditions, we will call zone F. North Dakota, northern South Dakota, Minnesota, northern Wisconsin, and northern Michigan have also the same climatic conditions, and therefore we will call this zone G.

The Weather Bureau has found the arerage time of the last killing frost in zone $\mathrm{E}$ to be between April 15 and May 1. In zone F between May 1 and May 15. In zone G between May 15 and June 1.

For convenience in studying the time of planting regetables, the United States Department of Agriculture has dirided regetable crops in to vegetable groups as follows:

Group 1. Consisting of early cabbage plants from hotbed or seed box, radishes, onion sets, early smooth peas, early potatoes, turnips, and mustard. These crops may be planted two weeks before the last killing frost.

Group 2. Consisting of heets, parsnips, carrots, lettuce: salsify, spinach, wrinkled peas, cauliflower plants, celery seed, onion seed, parsley, and sweet corn. These crops may be planted about the date of the last killing frost.

Grour 3. Consisting of snap beans, okra, and tomato plants. These crops should be planted two weeks after danger of frost is over. 
Grovp 4. Consisting of lima beans, pepper plants, eggplant, cucumbers, melons, squash, and sweet potatoes. These crops can not be planted until all danger of frost is over, which is about four weeks after the last killing frost.

The following diagram illustrates the planting dates of the above vegetable groups:

\begin{tabular}{|c|c|c|c|c|c|c|c|c|}
\hline Zone. & \multicolumn{2}{|r|}{ Group 1.} & \multicolumn{3}{|c|}{ Group 2.} & \multicolumn{2}{|r|}{ Group 3.} & Group 4. \\
\hline E... & Mar & 15-Apr. 15 & Apr. & 15-Мay & 1 & May & 1-May 15 & May $15-J u n e ~ 1$ \\
\hline F...... & Apr & 15-Маy 1 & May & 1-May & 15 & May & 15-June 1 & May 15-June 15 \\
\hline G..... & May & 1-May 15 & May & 15-June & 1 & May & 15-June 15 & Season too short. \\
\hline
\end{tabular}

\section{Lesson Twelve: HOW TO PLANT.}

Quantity of sceds or number of plants required for a row of 100 feet in length, with distance apart in rows, depth of planting, and average days required for maturity.

\begin{tabular}{|c|c|c|c|c|}
\hline Kind of vegetable. & $\begin{array}{l}\text { Seeds or plants re- } \\
\text { quired for } 100 \text { feet. }\end{array}$ & $\begin{array}{l}\text { Planted apart in } \\
\text { rows. }\end{array}$ & Depth of planting. & $\begin{array}{l}\text { Ready for use after } \\
\text { planting. }\end{array}$ \\
\hline Beans, bush. & 1 pint .... & 5 to 8 inches... & $\frac{1}{2}$ to 1 inch.... & 40 to 65 days. \\
\hline Beans, pole... & $\frac{1}{2}$ pint ....... & 3 to 4 feet...... & 1 to 2 inches.. & 50 to 80 days. \\
\hline Beets............ & 2 ounces....... & 5 to 8 inches..... & 1 to 2 inches... & 60 to 80 days. \\
\hline Cabbage, early..... & $\frac{1}{4}$ ounce....... & 12 to 18 inches... & $\frac{1}{2}$ inch ......... & 90 to 130 days. \\
\hline Cabbage, late... & $\frac{1}{4}$ ounce..... . & 16. to 24 inches... & $\frac{1}{2}$ inch ....... & 90 to 130 days. \\
\hline Carrot.......... & 1 ounce...... & 6 to 10 inches.... & $\frac{1}{2}$ inch ....... & 75 to 110 days. \\
\hline Celery ........... & $\frac{1}{4}$ ounce...... & 4 to 8 inches..... & $\frac{1}{8}$ inch $\ldots . . .$. & 120 to 150 days. \\
\hline Corn, sweet.... & $\frac{1}{4}$ pint $\ldots . . .$. & 30 to 36 inches... & 1 to 2 inches.. & 60 to 100 days. \\
\hline Cucumber..... & $\frac{1}{2}$ ounce...... & 4 to 6 feet....... & 1 to 2 inches... & 60 to 80 days. \\
\hline Lettuce......... & $\frac{1}{2}$ ounce ....... & 4 to 6 inches.... & $\frac{1}{2}$ inch ........ & 60 to 90 days. \\
\hline Muskmelon...... & $\frac{1}{2}$ ounce...... & Hills, 6 feet..... & 1 to 2 inches... & 120 to 150 days. \\
\hline Watermelon...... & 1 ounce....... & Hills, 10 feet.... & 1 to 2 inches... & 100 to 120 days. \\
\hline Onion seed.... & 1 ounce....... & 4 to 6 inches.... & $\frac{1}{2}$ to 1 inch..... & 130 to 150 days. \\
\hline Onion sets.... & 1 quart........ & 4 to 8 inches.... & 1 to 2 inches.. & 90 to 120 days. \\
\hline Parsnip . ...... & $\frac{1}{2}$ ounce...... & 5 to 8 inches.... & $\frac{1}{2}$ to 1 inch.... & 125 to 160 days. \\
\hline Peas........... & 1 to 2 pints.... & 15 to foot....... & 2 to 3 inches.. & 40 to 80 days. \\
\hline Pepper....... & $\frac{1}{8}$ ounce...... & 15 to 18 inches.. & $\frac{1}{2}$ inch ........ & 100 to 140 days. \\
\hline Potato, Irish..... & 5 pounds..... & 14 to 18 inches.. & 4 inches...... & 80 to 140 day's. \\
\hline Radish.......... & 1 ounce...... & 8 to 12 to foot... & $\frac{1}{2}$ to 1 inch.... & 20 to 40 days. \\
\hline Rhubarb seed........ & $\frac{1}{2}$ ounce....... & 6 to 8 inches.... & $\frac{1}{2}$ to 1 inch.... & 2 to 4 years. \\
\hline Rhubarb plants.... & 33 plants . . . . . & 3 feet.......... & 2 to 3 inches... & 1 to 3 years. \\
\hline Rutabaga....... & $\frac{1}{4}$ ounce...... & 6 to 8 inches.... & $\frac{1}{2}$ to 1 inch... & 60 to 80 days. \\
\hline Salsify ............ & 1 ounce...... & 2 to 4 inches.... & $\frac{1}{2}$ to 1 inch.... & 120 to 180 days. \\
\hline Spinach.......... & 1 ounce...... & 7 or 8 to foot..... & 1 to 2 inches.. & 30 to 60 days. \\
\hline Squash, bush...... & $\frac{1}{2}$ ounce...... & IIills, 3 to 4 feet. & 1 to 2 inches... & 60 to 80 days. \\
\hline Squash, late........ & $\frac{1}{2}$ ounce ...... & Hills, 7 to 9 feet.. & 1 to 2 inches...... & 120 to 160 days. \\
\hline Tomato........... & $\frac{1}{8}$ ounce....... & 3 feet (plants)... & $\frac{1}{2}$ to 1 inch...... & 100 to 140 days. \\
\hline Turnip............ & $\frac{1}{2}$ ounce...... & 6 to 7 to foot.... & $\frac{1}{4}$ to $\frac{1}{2}$ inch....... & 60 to 80 days. \\
\hline
\end{tabular}

The distance in inches the rows are apart will be found by consulting lessons 6 and 7 . Part of the data contained in the above table was taken from Farmers' Bulletin No. S1S. 


\section{Lesson Thirteen: COMMERCIAL FERTILIZERS FOR THE GARDEN.}

Compost, manure from the stable, henhouse, or pigeon loft, are the best fertilizers for the garden. When these are not available in sufficient quantities then we find it necessary to seeure commercial fertilizers. It is also often advisable to use commercial fertilizers as a supplement to manure.

For a garden eontaining 1,000 to 1,250 square feet, 10 pounds of nitrate of soda and 30 pounds of acid phosphate will make a good applieation. The nitrate of soda is applied by placing half of the quantity in the row at planting time and the other half scattered broadcast and raked into the soil. A ton of stable manure could be used on a garden 1,000 or 1,250 square feet in size. Results on a garden of the above size would be better, however, if to this amount of stable fertilizer 50 pounds of acid phosphate eould be added and well raked in just as soon as the ground is plowed.

Most seed and fertilizer houses now sell ready-prepared garden fertilizers. These ean be purchased in small quantities. A good garden fertilizer will eontain 3 to 5 per cent nitrogen 8 to 10 per cent phosphoric acid, and 2 per cent potash. The dealer will explain the best mixtures for the different types of soil. Most gardeners eount on using about 5 pounds of eommercial fertilizer for each 100 square feet of garden space. For a small supply of potash add 150 pounds of unleached hardwood ashes. These ashes serve a double purpose, since they contain about 30 per cent of lime.

A little study of the best methods of using commercial fertilizers on any garden will yield the gardener a splendid reward for his time spent.

\section{Lesson Fourteen: TESTING GARDEN SEED.}

Reliable seed houses and successful gardeners make it a part of their business to earefully test their seeds they plant or sell. Even when this is done, it sometimes happens that before the seeds are planted their vitality is injured.

\section{TESTING-A SIMPLE PROCESS.}

The testing of seeds may be accomplished by using any of the following plans:

1. Take a chalk box and fill it with sant. Plant 100 sects in the sand. See lesson No. 12 for depth of planting. Cover this chalk box with some glass and keep in a temperature of about $70^{\lrcorner} \mathrm{F}$. Note percentage of seed that germinates. Number the box. Number the paekage of seed to correspond with the number on the box. This plan is to remind us whieh package is being tested.

2. Moisten sheets of blotting paper. Between two sheets of the paper place 100 hundred seeds. Keep in a warm room. Note percentage of germination. Number the sheets. Number the package to correspond to the number on the sheets.

3. Fill two small bags with sawdust. Moisten these bags. Place 100 seeds between these bags and note percentage that germinates. Be sure to keep in warm place. Number the bags. Place same number on package as you do on bags.

By testing seed we determine not only the percentage that will germinate, but also the strength of the seed germ. When seeds show a very weak germ we eonclude they are not fit to plant. Garden seed that most gardeners consider good to plant show that 75 per cent of them will germinate and produce a strong germ. If they show a smaller percentage of germination, we must either discard the entire package that is being tested as unfit to plant or sow more thiekly than lesson No. 12 suggested to make up for the weak or inferior seeds. The better plan woulit likely be to discard package from which samples were taken that show a low pereentage of germination and an inferior germ and get new seed. If you use this plan of sowing thiekly, it means thinning out later as well as an uneven stand of plants. You will also be likely to have plants that are very irregular in growth and maturity. The best gardeners always test seed before planting. 


\section{Group II.--PLANTING AND CARING FOR THE CROPS.}

\section{Lesson Fifteen: GROWING AND TRANSPLANTING PLANTS.}

Garden plants may be grown in a limited way from seeds by using shallow boxes set in a sunny window of a dwelling house. The soil used should be rich and mellow and be collected in the fall for the seed boxes.

Plant the seed in rows in the box. Mark at the end of each row on the box the kind and variety of seed planted. When the plants reach a height of 3 or 4 inches or contain two or three leaves, transplant them to other boxes, setting 2 or 3 inches apart. This will enable them to grow more rapidly and to get a good root system before being again transplanted to the cold frame or garden.

Some gardeners transplant from the first box to individual pots or berry boxes. When this is done, the plants may later be taken from these pots or berry boxes without destroying their root system or delaying growth. If this plan mentioned above is carefully followed a garden may be planterl with good-sized plants at a very early date. Then we may also plan our box planting in order that later plants may be realy for planting as fast as the early crops have been harrested. For example, pepper and tomato plants should be ready to place in the gardens as fast as the earliest lettuce and radishes have been used. Care, however, should be exercised in planting out tender plants like the tomato and pepper, as they are likely to be killed by frost. For information on the dates of planting, see lesson No. 11. We also suggest that the new plants be covered at night with newspaper until you are sure they will not be frosted.

When plants are to be taken out of boxes or cold frames, they should be thoroughly watered, so that soil will adhere to the roots. After they are pulled the plants should be set out at once. If this is impossible, however, they can be kept a few hours by being covered with a damp cloth to prevent wilting.

If the soil is very dry at the time of transplanting, all plants should be watered out. 'This may be done by making the holes and filling them with water a few minutes before you are ready to do the transplanting. Before the water is poured in, fill holes about one-fourth full of fine soil. Place the plant roots into the damp soil at the bottom of the hole. Press this damp soil firmly about the roots and cover all damp earth with dry soil. This plan will help to hold the moisture until the plant takes root. If the plants have too much foliage, a part of the leaves should be removed to prevent their evaporating more moisture than the roots are able to take up. All transplanting should be done late in the afternoon or evening.

If the weather is cool and sufficient rainfall exists, then the transplanted plants will soon be growing well in their new location. If the weather is hot and the soil very dry, we should water all the transplanted plants a little each evening until they begin to show signs of growing.

\section{Lesson Sixteen: THINNING THE CROPS.}

We may use the very best plans possible in testing and planting and still not always succeed in getting a uniform stand. In our anxiety to get a sufficient number of plants, we frequently get the seed too thick. Then sometimes the weather conditions are so favorable for germination and growth, that even inferior seeds seem to procluce a fairly good plant. 
The above results make it necessary to thin the plants in the rows. This thinning of plants makes it possible for the gardener to eradicate all weak and inferior plants.

Thinning insures large and uniform specimens. Plants like the carrot, beet, radish, turnip, salsify, and onion can not grow and develop smooth roots if crowded. For this reason thinning is necessary. Other garden crops will also be improved, if they are too thick, by thinning.

For instruction in the distance that plants should stand in the rows see lesson No. 12 Thinning, therefore, will permit of ample room for all plants to grow and insure their natural development.

\section{Lesson Seventeen: REPLANTING THE CROPS.}

Replanting is the opposite of thinning. It is made necessary by poor seed, unfavorable weather conditions, or improper planting. Replanting is necessary in order that all garden space may be utilized and the maximum crop yields may be secured. We should replant the vacant spaces just as soon as we discover the seed sown have not sprouted or the plants that were planted have died or been destroyed by insects.

In replanting, place new plants as nearly as possible where the former seed or plants failed to grow.

We can sometimes secure plants for replanting from the rows that were thinned as described above. Where seed are used for replanting soak them a few hours in warm water and by so doing they will germinate more quickly.

\section{Lesson Eighteen: LETTUCE.}

SOIL AND CLIMATE.

Lettuce is usually one of the earliest garden plants sown. It thrives best in cool weather, and for this reason we should plant the seeds or plants early in the spring or late fall. It grows best in a rich sandy soil that contains considerable humus. Lettuce grown during the summer months in the sun is of little value except for garnishing. Summer-grown lettuce for the table should be planted in a location that is partially shaded.

\section{PLANTING AND CULTIVATION.}

Lettuce seed may be sown broadcast in a bed and the leaves removed from the plants as rapidly as they become large enough to use. A better method, however, is to transplant the seedlings in rows and thin as needed when plants are large enough for the table. If the heading type is planted, the plants should be thinned to 10 inches in a row and permitted to grow until compact heads are formed. At this time the entire plant may be cut for use. The soil in the lettuce bed should be well pulverized. Sow the seed and rake in with the garden rake. Cover seed with about half an inch of soil.

The plants require frequent shallow cultivation. The bed should be kept free from weeds. The leaves or head is more crisp if the crop is forced and successive plantings are made 10 days or 2 weeks apart throughout the early spring and late fall.

For a very early crop lettuce should be started in a hotbed or indoor box and the plants transplanted to the garden as soon as there is no further danger of a hard freeze.

VARIETIES.

(a) Leaf: Grand Rapids, Blacksceded Simpson.

(b) Head: Big Boston, May King. 


\section{Lesson Nineteen: RADISHES.}

SOIL AND CLIMATE.

Radishes do best in a rich soil. If sown in a poor soil and their growth is slow, their quality is not first class. Radishes are better grown in cool rather than in hot weather; hence we should plant the seed in early spring or late fall.

The seed may be sown in the open ground as soon as the soil is moderately warm.

Planting and CUltivation.

The seed should be covered about one-half inch deep with very fine soil. Plant 1 inch apart in the row, using an ounce of seed for one hundred feet of row space. For a constant supply, plant seed about every two weeks during spring and fall months. Begin using as early as possible, as the roots lose their crispness and delicate flavor if allowed to remain too long in the open ground. The thinning of the plants permit those that remain to have more space for growth.

Cultivate frequently in order that the soil may be kept loose about the roots of the plant. Keep rows free from weeds.

VARIETIES.

(a) Early: Scarlet Globe and Short Top.

(b) Summer: White Icicle.

(c) Winter: Japanese.

Lesson Twenty: PEAS.

SOIL AND CLIMATE.

Peas require rich, mellow soil, made firm by thorough working. The first crop should be planted as early as the soil can be worked. Peas are not injured by light frosts.

PLANTING AND CULTIVATION.

Peas should be covered about 2 inches deep with fine soil, and be planted every two weeks until hot weather, to insure a continuous supply. Plant about 15 seeds to the foot, using 1 to 2 pints for 100 feet of row space. Some gardeners plant in double rows 6 to 8 inches apart and 3 to 4 feet between the double rows. This plan is specially advisable when varieties requiring support are used. The support is placed between the double row. Brush, wire netting, or stakes are used for supports when large growing varieties are planted. The wire netting should be tacked firmly to stakes which are located about every 8 feet in the row. When strings are used on stakes place same about 4 inches apart. Drive stakes containing either netting or strings about 10 inches into the soil so as to produce a firm support for the pea vines. Cultivate frequently. As the vines get larger, pull the dirt up to give them support.

VARIETIES.

The first plantings should consist of the dwarf, quick-maturing varieties like the Gradus and Alaska. Follow with the wrinkled type like the Telephone and Champion of England. For the fall garden use the early dwarf varieties. 


\title{
Lesson Twenty-one: ONIONS.
}

\author{
SOIL AND CLIMATE.
}

Onions do best on well-drained loams that contain a large amount of humus. They may be produced in all temperate climates.

PLANTING AND CULTIVATION.

For a crop of dry onions use 1 ounce of seed for 100 feet of row space, planting seed $1 \frac{1}{2}$ inches apart in a row and covering with 1 inch of fine soil. When early bulbs are desired, plant seed in a hotbed or indoor seed box. Transplant the plants to the soil as early as it can be worked. Plants 4 or 5 inches high are the best size for transplanting. When sets are planted use 1 quart to 100 feet of row space, placing about 2 inches apart in a row and 1 to 2 inclies deep.

Early spring onions may be produced by planting Multipliers in the fall. If only the new growth is desired for food, plant unused old onions that have already started to grow. Onions require shallow cultivation and hand weeding.

(a) Sets: White Silverskin.

VARIETIES.

(b) For Dry Onions: Yellow Globe, Silver King.

\section{Lesson Twenty-two: IRISH POTATOES.}

The Irish potato is a native of America, but was called Irish potato after its introduction into Ireland.

\author{
SOIL AND CLIMATE.
}

The Irish potato is grown successfully in nearly all parts of the United States and many countries of the Old World. It grows best on a well-drained, sandy loam that is rich in humus.

\section{PLANTING AND CULTIVATION.}

Irish potatoes are plinted in rows 2 to $21 / 2$ feet apart, using 4 to 6 pounds of seed for 100 feet of row space. The seed potatoes, called "tubers," are planted 3 to 4 inches deep and the plants should stand about 15 inches apart in the row. Early potatoes should be planted as soon as the ground can be worked. Late potatoes are planted from the last week in May to the first week in July. T'hey require consideruble water for their successful growth. For this reason the moisture in the ground should be conserved by frequent cultivation. Toward the last of the season pull the dirt up well around the vines to protect the tubers from the sun after the vines aie.

\section{VARIETIES.}

Early: Early Ohin, Early Rose, and Irish Cobbler.

Late: Green Nountain, Rural New Yorker, and Sir Walter Raleigh. 


\title{
Lesson Twenty-three: BEETS.
}

\author{
SOIL AND CLIMATE.
}

Beets can be grown in almost any climate in the country, but do best in a moist, welldrained soil. They grow well in cool climates, hence larger crops are grown in the North. The seed can be planted as early in the spring as the ground can be worked. It is not necessary for the ground to become warm before planting the seed.

\section{PLANTING AND CULTIVATION.}

The seer should be planted 1 to 2 inches deep, at the rate of 2 ounces to 100 feet of row space. The plants should be thinned so that they stand about 6 inches apart in the row. Do not waste the plants taken out. T'ransplant them to other grarlen space if you have it or use the tops for greens. Perhaps some young gardener in the neighborhoorl would be glad to have your surplus plants. The rows are usually placed about 12 or 18 inches apart. To insure a supply of young tender beets throughout the season, it is arlvisable to make three or four plantings. Under favorable weather conditions, beets will be ready for use in from 60 to 80 days.

\section{VARIETIES.}

Reliable varieties include: Crosby's Egyptian, Y'ellow Turnip, Detroit Red, Eclipse.

\section{Lesson Twenty-four: CABBAGE.}

SOIL AND CLIMATE.

Cabbage to mature early requires a rich, warm, mellow soil. The seed of the early varieties may be sown in a hotbed or indoor seed box. The plants are hardy and will stand a light frost. Cabbage can be left in the garden until cool weather without injury to the heads.

\section{PLANTING AND CULTIVATION.}

The plants should be transplanted as soon as the soil can be placed in good condition. They should be placed about 12 to is inches apart in the row and one-half to 1 inch deep. The rows should be from 30 to 36 inches apart for convenient cultivation with the wheel hoe. Seed for the fall crop should be planted in June. Transplant the plants as soon as they are about 4 inches in height, and the soil contains sufficient moisture to insure their proper growth.

\section{VARIETIES.}

Early: Jersey Wakefield, Copenhagen.

Late: Flat Dutch, Danish Bull Head.

\section{CHINESE CABBAGE.}

This plant is closely related to the turnip and may be used either as a potherb or as a salad. It is most frequently used as greens during the spring months because of the difficulty of getting it to head during this season. The growth and cultivation of Chinese cabbage is like that for the common cabbage. It needs a rich, well-drained soil but also plenty of moisture. For a late crop plant about the same time as you would fall turnips. This plant matures in much less time than ordinary cabbage. 


\section{Lesson Twenty-five: CARROTS.}

SOIL AND CLIMATE.

The soil and climatic conditions under which parsnips do best are also favorable to the carrot.

\section{PLANTiNg AND CULTivation.}

The seed should be planted one-half inch deep, using 1 ounce to 100 feet of row space. The plants should stand 2 inches apart in the rows; if too thick, transplant your surplus plants to other garden space. Cultivation should begin when plant is 1 inch high. By marking the rows with radishes, as suggested under leaflet on parsnips, cultivation may begin before the carrot plants have come through the ground. The growth may be hastened by the application of a small amount of fertilizer on each side of the row. When plants are large enough to touch each other in the row the larger ones should be pulled for table use.

\section{VARIETIES.}

If the carrots are planted in a clay soil that tends to become hard, the short variety known as the Golden Ball should be used. This variety and the Early Scarlet Horn are best for early planting. The longer types like the French Forcing, Half Long Scarlet, Oxheart, and Long Orange are later varieties, and require soil that is deep and mellow for their most successful development. 


\section{SUGGESTIONS AS TO ORGANIZATION.}

The following suggestions are submitted to teachers and supervisors in the hope that they may be helpful in promoting the organization of the unit companies of this Army:

Number of members in a company.--Ten to one hundred and fifty.

Age limit.-Any school child, but preferably the more important companies should be enlisted from the pupils above the third grade.

Requirements for enlistments.-The signing of an enlistment sheet in which the pupil agrees to raise one or more food crops and to keep records of his work and the results, reporting them to the teacher or garden supervisor. These sheets will be furnished by the Bureau of Education.

A company.-The maximum number of soldiers in a company is 150 .

Officers.-Each company to have a captain and one or more lieutenants, the latter depending upon the number of soldiers enlisted.

Insignia.-For the private, a bronze and black enameled bar with U. S. S. G. on it. For the second lieutenant, a bronze bar with one star in the border. For the first lieutenant, a bronze bar with two stars in the border. For the captain, a bronze and black enameled double bar. These insignia will be furnished by us upon request, stating the number of enlisted garden soldiers.

Entistments of existing organizations.-Any organization of school children now doing garden work will be eligible to enlistment. Such organizations may keep their existing form, if they so desire, and have the additional impetus of belonging to a national army fostered by President Wilson, the Secretary of the Interior, and the Commissioner of Education. The aim of this army is to nationalize and unify the great work now being carried on among the school children of America.

18

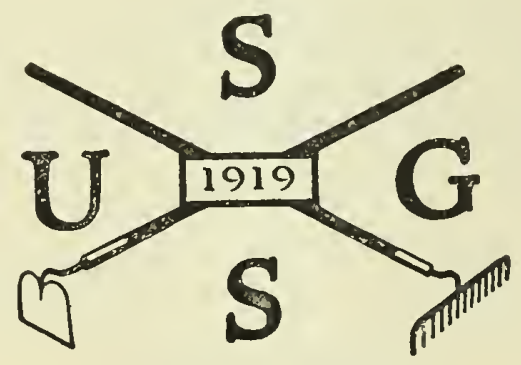





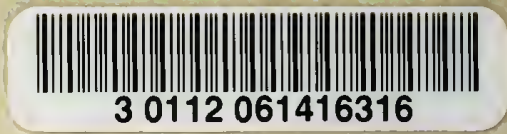

